\title{
Exploitation of Denaturing Gradient Gel Electrophoresis in Analysis of Microbial Diversity
}

\section{Shah MP*}

Industrial Waste Water Research Laboratory, Division of Applied and Environmental Microbiology, Enviro Technology Limited, Gujarat, India

\begin{abstract}
An application of gradient gel electrophoresis of the PCR-amplified gene fragments were hydrogenase. Comparative analysis of the [NiFe] hydrogenase gene sequences were designed with five different PCR primers. These primers were tested in various combinations on genomic DNA from different hydrogenase-containing and hydrogenase lacking bacteria. For desulfovibrio species appeared to be only one primer pair specific, while others gave positive results with other bacteria. By using this specific pair of primers, we were able to amplify the [NiFe] hydrogenase genes. However, only after could be set DGGE analysis of these PCR products by the number of different species of desulfovibrio in the samples. DGGE analysis of PCR products from different bioreactors demonstrated up to two radicals, wherein at least five distinguishable bands were detected in the microbial mat sample. Because these groups are probably as many desulfovibrio species in these samples, we conclude that the genetic diversity in the species desulfovibrio natural microbial mat is much greater than in experimental bioreactors.
\end{abstract}

Keywords: Desulfovibrio; PCR; DGGE; Hydrogenase

\section{Introduction}

Sulfate-reducing bacteria (SRB) form a phylogenetically diverse and heterogeneous group of anaerobic bacteria using sulfate as a terminal electron acceptor in the degradation of organic matter, resulting in the production of $\mathrm{H}_{2} \mathrm{~S}$. They are ubiquitous and play an important role in the biogeochemical sulfur cycle. Sulfate reduction dominates the organic matter degradation in environments with high concentrations of sulfate. It has been estimated, for instance, that sulfate reduction accounts for up to $50 \%$ of the total organic matter degradation in marine sediments [1]. Apart from marine sediments, their presence has also been demonstrated in other environments, such as freshwater lake sediments [2], anaerobic biofilms [3,4], oil production facilities [5], and wastewater treatment plants [6]. Although SRB are generally considered to be obligatory anaerobic bacteria, they have also been detected in aerobic environments, such as the oxic zones of cyanobacterial mats [7] and wastewater biofilms grown under oxic conditions [8]. Because of the importance of SRB to critical processes in ecosystem functioning and environmental remediation, in- creasing interest in SRB has been shown over the last decade. Different culture-independent methods have been used to study SRB populations in various ecosystems, resulting in an increased knowledge of their diversity. 16S rRNA-targeted oligonucleotide probes specific for SRB have been used in fluorescence in situ hybridization for the detection of these microorganisms in a variety of environments [9]. Genes encoding important enzymes in the sulfur cycle have also been used to detect sulfate-reducing bacteria in different environments [10,11]. 16SrRNA-targeted PCR primer sequences specific for SRB subgroups have been designed and used to detect phylogenetic subgroups of SRB [12]. Recently, a DNA microarray suitable for SRB diversity analysis has been developed and applied to detect SRB in complex environmental samples [13]. Denaturing gradient gel electrophoresis (DGGE) of PCR- amplified DNA fragments is another molecular tool that has been used to determine the presence and distribution of SRB in natural and engineered environments [14]. However, although successful, the banding pattern represents mainly the major constituents of the analysed community [15]. Species that contribute less than $1 \%$ of the total population would not be readily detected by this molecular approach [16]. Here, we present another approach to detect SRB in environmental samples and to perceive their ecological role. This approach consists of a combination of PCR [17], to amplify the [NiFe] hydrogenase gene from Desulfovibrio species, and denaturing gradient gel electrophoresis (DGGE) [18-20]. We have chosen the $[\mathrm{NiFe}]$ hydrogenase gene, because it encodes an enzyme which plays an important role in the hydrogen metabolism of SRB [21] and in the dissimilatory metal reduction by SRB [21,22] and because it is present in all Desulfovibrio species [23]. This makes it an excellent molecular marker to study the distribution of Desulfovibrio species in natural samples, as well as their metabolic activity. We have applied DGGE of the PCR products of this gene to discriminate between different Desulfovibrio species in environmental samples. In DGGE, DNA fragments of the same length but with different base pair sequences, such as PCR fragments obtained from a mixture of target DNAs, can be separated. The technique was recently introduced in the field of molecular microbial ecology to analyze the genetic diversity of bacterial populations $[24,25]$ and to identify the phylogenetic affiliation of individual population members [26]. This report describes the first step in our goal to perceive the niche differentiation of Desulfovibrio species in natural samples. It describes the application of DGGE analysis of PCR-amplified [NiFe] hydrogenase fragments to determine the genetic diversity of Desulfovibrio species in natural samples.

\section{Materials and Methods}

\section{Sample collection and bacteria}

We have used a wide range of hydrogenase-containing and hydrogenase-lacking of bacteria in this study (Table 1). Desulfobulbus-

${ }^{*}$ Corresponding author: Shah MP, Industrial Waste Water Research Laboratory, Division of Applied and Environmental Microbiology, Enviro Technology Limited, Gujarat, India, Tel: +91-9099965504; E-mail: shahmp@uniphos.com

Received March 12, 2015; Accepted March 25, 2015; Published April 01, 2015

Citation: Shah MP (2015) Exploitation of Denaturing Gradient Gel Electrophoresis in Analysis of Microbial Diversity. J Microb Biochem Technol 7: 112-119. doi:10.4172/1948-5948.1000191

Copyright: (c) 2015 Shah MP. This is an open-access article distributed under the terms of the Creative Commons Attribution License, which permits unrestricted use, distribution, and reproduction in any medium, provided the original author and source are credited 


\begin{tabular}{|c|c|c|}
\hline Primer $^{\mathrm{a}}$ & Position ${ }^{b}$ & Sequence \\
\hline Hyd2F & $811-829$ & $5^{\prime}-\mathrm{CCGG}(\mathrm{C} / \mathrm{T}) \mathrm{TGCCCGCC}(\mathrm{G} / \mathrm{C}) \mathrm{AACCC}-3^{`}$ \\
\hline Hyd1F & $1441-1467$ & 5'-CGCGACGCCCAGCACTTCACCCAGCGC-3’ \\
\hline Hyd4F & $1786-1815$ & 5'-TTCACCAA(C/T)GCCTACTTCCT(G/C)GGCGGCCAC-3’ \\
\hline Hyd5F & $1844-1879$ & 5'-GCAGGGCTTCCAGGTAGTGGGCGGTGGCGATGAGGT-3` \\
\hline Hyd7F & $2859-2878$ & 5'-CGCAGGCGATGCA(G/C)GGGTC-3’ \\
\hline GC clamp ${ }^{c}$ & & 5'-CGCCCGCCGCGCCCCGCGCCCGTCCCGCCGCCCCCGCCCG-3` \\
\hline
\end{tabular}

${ }^{a}$ The forward and reverse primers are indicated by the last letters $F$ and $R$, respectively.

${ }^{b}$ Positions in the [NiFe] hydrogenase gene of D.vulgaris [8]

${ }^{c}$ The GC clamp is attached to the 59 end of the Hyd1F primer.

Table 1: Primer sequences and positions.

\begin{tabular}{|c|c|c|c|c|c|c|}
\hline \multirow[t]{2}{*}{ Organism } & \multirow[t]{2}{*}{ Source $^{a}$} & \multicolumn{2}{|c|}{ Type } & \multirow[t]{2}{*}{ Serotype(s) ${ }^{b}$} & \multicolumn{2}{|c|}{ PCR amplification ${ }^{c}$} \\
\hline & & Morphology ${ }^{d}$ & Environment (s) & & EUB primers & NIT primers \\
\hline Thiobacillusdenitrificans ATCC 25259 & $\mathrm{i}$ & $\mathrm{R}$ & Soil & ND & + & - \\
\hline Chromobacteriumviolaceum ATCC 12472 & $\mathrm{i}$ & $\mathrm{R}$ & Freshwater & ND & + & - \\
\hline Rhodospirillumrubrum ATCC 33512 & $\mathrm{i}$ & $\mathrm{R}$ & Pond & ND & + & - \\
\hline R.purpureus & j & $\mathrm{RR}$ & Waste pond & ND & + & - \\
\hline Rhodocyclus tenuis ATCC 25093 & $\mathrm{i}$ & $\mathrm{R}$ & Pond & ND & + & - \\
\hline R.galatinosus & j & C & Pond & ND & + & - \\
\hline
\end{tabular}

aa, E.L. Schmidt; b, S.W.Watson; c, A.F. Carlucci; d, B.B. Ward; e, S.G. Horigan; f, J.Zyskind; g, D. Castignetti; h, M.Pontius-Brewer; i, American Type Culture Collection; j, M.T.Madigan

${ }^{\mathrm{b} A c c o r d i n g}$ to reference $34, \mathrm{Nm}$, marine Nitrosomonas sp.; No, N.oceanus; Nb, Nitrobacter sp.; Ng, N.gracilis; NR, no reaction; ND, not determined.

${ }^{c_{+}}$, amplified product of correct size ; -, no amplification.

${ }^{\mathrm{d}} \mathrm{C}$, coccoid; R, rod; V, vibrio; RR, ring shaped or rod; S, spiral; L, lobular

Table 2: PCR amplification of known strains and environmental isolates with a set of EUB primers and a set of NIT primers.

like bacterium was isolated from activated sludge from wastewater. Sulphate reducing bacteria was isolated from the common waste water treatment in India.

\section{DNA extraction}

Genomic DNA was extracted from samples using the MoBio PowerSoil DNA kit. Nucleic acids from all Sterivex filters were extracted according to a previously published protocol [27]. The quality and quantity of extracted DNA were measured by agarose gel electrophoresis and spectrophotometry respectively. Extracted DNA was then diluted to 5-10 ng $\mu \mathrm{L}^{-1}$ for use as PCR template.

\section{PCR amplification}

PCR amplification was performed with a Techne PHC-3 Temperature Cycler as follows: $10-100$ ng of purified genomic DNA or 1-5 $\mathrm{ml}$ of cell lysate, $25 \mathrm{pmol}$ each of the appropriate primers, 200 mmole each deoxyribonucleoside triphosphate, and $5 \mathrm{ml}$ of 103 PCR buffer (100 mM Tris- $\mathrm{HCl}$ [pH 9], $15 \mathrm{mM} \mathrm{MgCl}, 500 \mathrm{mM} \mathrm{KCl}, 0.1 \%$ $[\mathrm{w} / \mathrm{v}]$ gelatin, $1 \%[\mathrm{v} / \mathrm{v}]$ Triton $\mathrm{X}-100)$ were added to $0.5 \mathrm{ml}$ volume of the test tube which was filled to a volume with sterile water to $50 \mathrm{ml}$ and covered with 2 drops of mineral oil. To minimize non-specific annealing of primers to non-target DNA polymerase Super Taq DNA was added to the reaction mixture after denaturation step $\left(94^{\circ} \mathrm{C}, 5 \mathrm{~min}\right)$ at $80^{\circ} \mathrm{C}$. In addition, for increasing the specificity of amplification and to reduce the formation of interfering by-products was conducted "' landing "' PCR [28]. Touchdown PCR is a PCR wherein the annealing temperature is set above the expected $10^{\circ} \mathrm{C}$ annealing temperature $\left(70^{\circ} \mathrm{C}\right)$, and decreased by $1^{\circ} \mathrm{C}$ per second to cycle contact $60^{\circ} \mathrm{C}$, at which temperature 10 additional cycles performed. Primer extension is performed at $72^{\circ} \mathrm{C}$ for 3 minutes. Amplification products were analyzed by electrophoresis in a $2 \%(\mathrm{w} / \mathrm{v}) \mathrm{NuSieve}$ agarose (FMC) gels containing ethidium bromide $(0.5 \mathrm{mg} / \mathrm{ml})$.

\section{Denaturing Gradient Gel Electrophoresis (DGGE)}

All samples were amplified by PCR with primers specific bacteria (341f-GC/518r) focused on the 16S rRNA gene. This PCR, except that the nested PCR approach for the detection Anammox bacteria followed previously published protocols [29]. Briefly, for the nested PCR, the template was amplified with specific primers Anammox bacteria An7f/An1388r, followed by amplification of specific bacteria DGGE primers 341f-GC/518r. Additional published primers were modified with GC clamps for assessment DGGE [30]. The Anammoxspecific nested PCR amplification involved either An7f/or An1388r Pla46/1392r for the first round of PCR, followed Anammox specific A438f-GC/or A684r Amx368f-GC/Amx820r for the second reaction. Components containing $2.5 \mathrm{ul}$ of PCR Thermo Pol 10x reaction buffer, $0.05 \mathrm{ml}$ forward and reverse primer (100 mM stocks), $0.05 \mathrm{ml}(100 \mathrm{mM}$ dNTP stocks), $0.1 \mathrm{ml}$ of Taq DNA polymerase (5 U UL 1 stock), 1.5 $\mathrm{ml}$ of bovine serum albumin (10 mg l-1 stock) and $1 \mathrm{ml}$ of the DNA template (representing 5 to $10 \mathrm{ng}$ of genomic DNA) in a total reaction volume of $25 \mathrm{ml}$. All PCR amplifications were performed with an initial denaturation at $95^{\circ} \mathrm{C}$ for 5 minutes, followed by a temperature cycling conditions of primer-specific-set (Table 2) with a total of 30-35 cycles in the first round of PCR and a final extension at $72^{\circ} \mathrm{C}$ for 10 minutes to complete the reaction. The first round PCR products were diluted 100 times, which will serve as a template for nested PCR. Nested PCR conditions and heat cycle profiles of each primer set were the same as described above, except the number of PCR cycles. All nested PCR were performed on a total of 2025 cycles. After each amplification, the PCR products were verified by agarose gel electrophoresis to confirm the size of the amplicon. In 341f-GC/518r and A438f-GC/A684r PCR products were performed on $10 \%$ acrylamide gels with $30 \%-70 \%$ denaturing gradients. Products Amx368f-GC/Amx820r PCR were profiled on $8 \%$ acrylamide gels with $30 \%-70 \%$ denaturing gradients. All DGGE gels were conducted for 15 hours at $85 \mathrm{~V}$ and at $60^{\circ} \mathrm{C}$ using DGGEK - 
2,401th These DGGE gels were stained with SYBR green and scanned with Pharos FXTM extra Molecular Imager. Representative bands were excised and sequenced specific primers corresponding Anammox in Beckman Coulter Genomics using an ABI 3730XL sequencer.

\section{Electroblotting}

When DGGE gel allowed to equilibrate in lx TBE ( $89 \mathrm{mM}$ Tris -borate $\mathrm{pH}$ [8X, $89 \mathrm{mM}$ boric acid, $2 \mathrm{mM}$ EDTA] for 15 minutes. Patterns polyacrylamide gel separation was transferred onto nylon membrane electrotransfer device consists of two carbon plates mounted in Plexiglas frame [32]. The electrotransfer was performed for about 45 minutes at a constant magnitude of current $400 \mathrm{~mA}(0.5$ $\left.\mathrm{mA} / \mathrm{cm}^{2}\right)$. Immediately after the transfer, the membrane is placed for 10 minutes on a piece of Whatman 3MM filter paper soaked in $0.4 \mathrm{M}$ $\mathrm{NaOH}, 0.6 \mathrm{M} \mathrm{NaCl}$ to denature the DNA. It was neutralized by being rinsed twice in a large volume of $2.5 \mathrm{x}$ SSC $(1 \mathrm{x}$ SSC is $150 \mathrm{mM} \mathrm{NaCl}$ and $15 \mathrm{mM}$ sodium citrate), and then was exposed for $45 \mathrm{sec}$ to $302 \mathrm{~nm}$ UV light to crosslink the DNA fragments on membrane .

\section{Hybridization analysis}

The Membrane is prehybridized for 2 hours at $50^{\circ} \mathrm{C}$ with $50 \mathrm{ml}$ solution containing $1 \%(\mathrm{w} / \mathrm{v})$ blocking reagent in $5 \mathrm{X} \mathrm{SSC}, 0.1 \%(\mathrm{w} / \mathrm{v})$ sodium dodecyl sulfate. One hundred nanograms to 32P-labelled oligonucleotide probe which is specific for sulphate-reducing bacteria (corresponding to positions 385-402 of the 16S rDNA sequence of E. coli) was added to the pre-hybridization solution and incubated overnight at $50^{\circ} \mathrm{C}$. The sequence of this probe has been described by Amann et al. [33]. After hybridization, the membrane was washed for 30 minutes at $50^{\circ} \mathrm{C}$, first a solution containing $2 \mathrm{X} \mathrm{SSC}, 0.1 \%(\mathrm{w} / \mathrm{v})$ SDS and then with one containing $0.1 x$ SSC $-0.1 \%(w / v)$ SDS. Subsequently, the membrane was sealed in a plastic bag and incubated with Kodak film at $-70^{\circ} \mathrm{C}$.

\section{Design of PCR primers}

Three [NiFe] hydrogenase sequences, viz., those of Desulfovibrio vulgaris [34], Desulfovibrio fructovorans [35], and Desulfovibrio gigas [36] were aligned to each other by using the BESTFIT program in the Sequence Analysis Software Package [37]. From these aligned sequences, seven consensus sequences were retrieved, five of which were used in this study. Figure 1 shows a schematic drawing of the positions of the primers. Table 1 gives the primer sequences and the exact locations. The primer sequences were compared with all of the sequences stored in the EMBL database by using the FASTA search program [38,39]. Significant similarity values were found with hydrogenase sequences only.

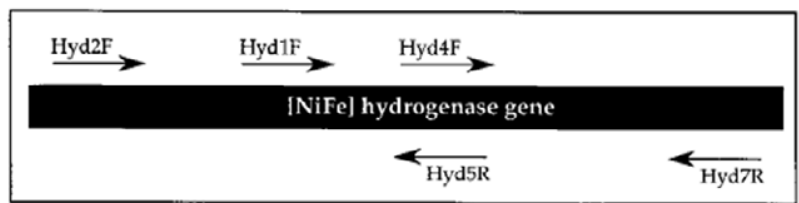

Figure 1: Schematic diagram of the primer positions in the [NiFe] hydrogenase gene of D.vulgaris. The following primer pairs were used to amplify the [NiFe] hydrogenase gene: Hyd2F-Hyd7R, Hyd1F- Hyd7R, Hyd4F-Hyd7R, Hyd2F-Hyd5R, Hyd1F-Hyd5R. In addition, Hyd4F was labelled with DIG and used as a probe in hybridization experiments to identify amplified hydrogenase sequences.

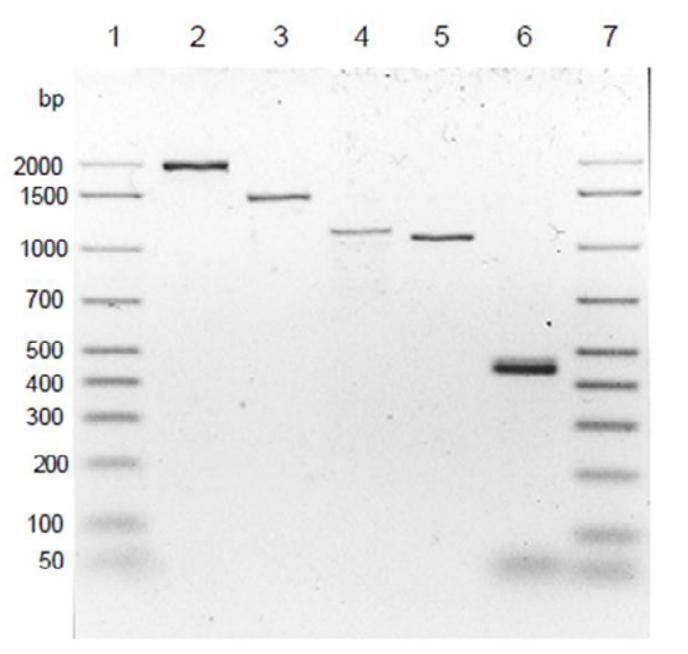

Figure 2: Negative image of an ethidium bromide-stained agarose gel with DNA fragments obtained after enzymatic amplification of the [NiFe] hydrogenase gene from genomic DNA of $D$. vulgaris BCMPS82 using the following primer pairs: Hyd2F-Hyd7R (lane 2), Hyd1F-Hyd7R (lane 3), Hyd4F-Hyd7R (lane 4), Hyd2F-Hyd5R (lane 5), and Hyd1F-Hyd5R (lane 6). DNA size markers (Bio-Rad) were applied to lanes 1 and 7.

\section{Polymerase chain reaction}

Subsequently, these primers were used to amplify the [NiFe] hydrogenase gene from genomic DNA of $D$. vulgaris BCMPS82. Figure 2 shows ethidium bromide stained agarose gel of PCR products obtained with primer pairs Hyd2F-Hyd7R, Hyd1F-Hyd7R, Hyd4F-Hyd7R, Hyd2F-Hyd5R and Hyd1FHyd5R (Figure 1 for the relative position of primers). Product sizes are in good agreement with the sizes calculated from the published sequence [40], namely, 2070, 1440, 1090, 1070 and $440 \mathrm{bp}$, respectively [41]. Explore the specificity of primer pairs are used in PCR to amplify the gene from genomic DNA of hydrogenase from different hydrogenase containing and lacking hydrogenase- bacteria Positive control for the presence of DNA is amplified 16S rRNA genes of bacteria (results not shown). Results of PCR hydrogenase knowledge-iments are summarized in Table 2. Amplification products were found mainly among all primer pairs and species Desulfovibrio. One primer pair, i.e. Hyd1F-Hyd5R was specific as possible; it only gave PCR products with genomic DNA from Desulfovibrio spp. and not with those of other bacteria. Other primer pairs amplified DNA sequence also from some other bacteria, including from bacteria that do not use hydrogen as Desulfococcus multivorans and Desulfoarculus baarsii. Voordouw et al. [42] also observed weak but reproducible hybridization signal for these species using hydrogenase gene probes. To reduce the formation of interfering by-products, we used so-called touchdown PCR protocol [43], wherein the annealing temperature is set at $70^{\circ} \mathrm{C}$ and $10^{\circ} \mathrm{C}$ above the expected annealing temperature $60^{\circ} \mathrm{C}$ and reduced to one cycle per second up to the abutment $60^{\circ} \mathrm{C}$, in which temperature 10 additional cycles is performed. However, by using this very strict protocol and PCR primer pair Hyd1F-Hyd5R, we obtained a low yield of PCR product for D. vulgaris BCMPS82 and no product for Desulfovibrio longus and Desulfovibrio salexigens. A better result, i.e., a higher yield of PCR product for D. vulgaris BCMPS82 and positive signal $D$. longus, is obtained when we used less stringent PCR protocol, i.e. landing $65-55^{\circ} \mathrm{C}$. However, at this annealing temperature was also found PCR products of other bacteria, although never the same size as those obtained from species of Desulfovibrio. Due to this low stringent PCR protocol has not been possible to obtain a PCR product 
D. salexigens this pair of primers. A positive signal for this species was obtained only primer pair Hyd2F-Hyd7R.

\section{Amplification}

Further experiments were performed with primer pair Hyd1FHyd5R only and landing PCR protocol $70-60^{\circ} \mathrm{C}$. These primers were used to amplify [NIDV] hydrogenase gene from environmental samples. Figure 3A shows ethidium bromide stained agarose gel of PCR products obtained from bacterial genomic DNA isolated from various environmental samples, such as microbial mat, and experimental waste water treatment reactors. Positive results were obtained with genomic DNA from three different anaerobic and biofilms of microbial mat sample (Figure 3, lane 5). (Figure 3, lanes 3, 6, and 7); DNA isolated from bacterial biofilm grown under aerobic conditions (Figure 3, lane 4) gave no PCR product. All PCR-amplified fragments of the same size, i.e., $440 \mathrm{bp}$, which was identical to the PCR product amplified from genomic DNA of two pure cultures D. vulgaris BCMPS82 (Figure 3, lane 1), and D. desulfuricans BCMPS79 (Figure 3, lane 9), respectively.

\section{Hybridization analysis}

To support the specificity of this hydrogenase gene amplification, we performed a hybridization analysis of the agarose separation pattern using the DIG-labelled probe Hyd4F, for which the target sequence is located within the amplified fragment (Figure 1). Figure 3B shows a photograph of the chemiluminescence results of this hybridization analysis. All of the expected hydrogenase bands were stained, while the DNA size standards were not.

\section{Theoretical melting behaviour}

DGGE was used to separate the putative hydrogenase gene fragments amplified from environmental samples. To optimize this analysis, DGGE, we used a software program called Melt87, developed by LS Lerman and E. Hovig. The program determines the theoretical melting map for the known sequence [44]. Figure 4 shows the melting map for the 440-bp [NiFe] hydrogenase D. vulgaris sequence (solid line). From this map, we can identify three melting domains: one of positions 1 to 200 with a melting point of about $81^{\circ} \mathrm{C}$, one of positions
A

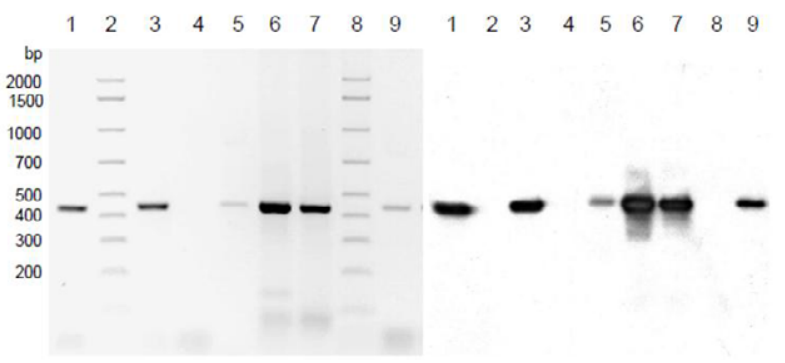

Figure 3: Detection of Desulfovibrio spp. in environmental samples by PCR amplification of the [NiFe] hydrogenase gene using primer pair Hyd1FHyd5R. (A) Negative image of an ethidium bromide-stained agarose gel with PCR products obtained from DNAs from bacteria isolated from a microbial mat (lane 5), bacteria grown under anaerobic conditions in wastewater treatment reactors (lanes 3,6 , and 7 ), bacteria grown under aerobic conditions in a wastewater treatment reactor (lane 4). Lanes 1 and 9 represent the PCR products obtained after amplification of the genomic DNAs from $D$. vulgaris BCMPS82 and $D$. desulfuricansA, respectively. Lanes 2 and 8 contain DNA size markers (Bio-Rad). (B) Results after hybridization analysis using the DIG-labelled oligonucleotide probe Hyd4F whose target sequence is located with in the amplified region.

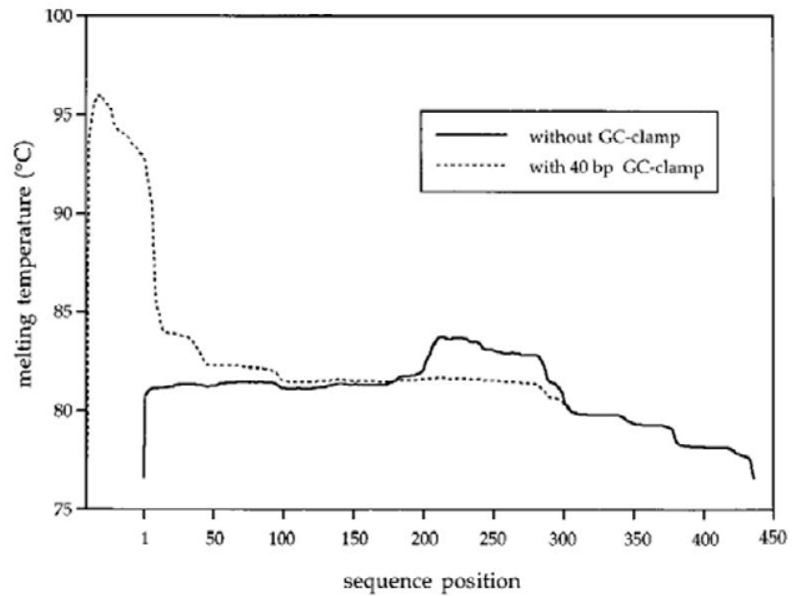

Figure 4: Theoretical melting map for the $D$. vulgaris [NiFe] hydrogenase sequence located between primers Hyd1F and Hyd5R. The solid line represents the melting map of the sequence without an attached $40-b p$ GCrich sequence. The dashed line represents the melting map of the same sequence but with a $40 \mathrm{bp}$ GC-rich sequence attached to the $5^{`}$ end.

201-300 with a melting point of about $84^{\circ} \mathrm{C}$ and one of positions 301 to 440 with an average melting point about $78^{\circ} \mathrm{C}$. The melting points of these three areas are so close together that they can be melted one at a time very quickly, resulting in two single strand molecules, which do not stop in the denaturing gradient gel. The dashed line represents the melting map for hydrogenase sequence with attached 40-bp GCrich sequence at its end 59 [45]. Here we also notice three melting domain; one of the positions 240-1 having a melting point of about $95^{\circ} \mathrm{C}$, generated $1234567 \mathrm{GC}$-rich sequences, one of positions 1 to 300 , melting point $82^{\circ} \mathrm{C}$ and melting domain from positions 301 to 440 , with identical temperature melting, as for the sequence without GC clamp. Here hydrogenase current sequence (position 1-440) was rapidly melted but two fibres are not completely separated, since they are held together by GC clamp, which has a melting point of about $95^{\circ} \mathrm{C}$. Only these fragments partially molten stops denaturing gradient gel. From these maps is also seen that the pattern of melting domains is characteristic of the whole fragment: adding a GC clamp on one end of the fragment changes the melting of large parts of the fragment [46].

\section{Perpendicular DGGE analysis}

An Experimental evidence for this behaviour was determined by the so-called melting perpendicular DGGE analysis [47]. Figure 5 depicts an ethidium bromide stained polyacrylamide gel analysis of two perpendicular DGGE PCR amplified [NiFe] hydrogenase from D. vulgaris gene fragments BCMPS82. One fragment had a GC clamp 59 attached to its end, had the second terminal. At low concentrations of DNA denaturants, from $0 \%$ to about $50 \%$ denaturing fragment is still double-stranded helical conformation and migrates depending on its size. At a concentration of about $50 \%$ denaturing fragment begins to melt, resulting in reduced mobility. However, without GC clamp fragments exhibit no stable behaviour during melting; is melted in two single stranded DNA molecules which gave fuzzy appearance perpendicular gel (Figure 5). To obtain a stable melting behaviour, both in Annex 40-bp GC-rich sequence at the front Hyd1F PCR primer. The melting curve similar to that for the fragment amplified without GC clamp primer was visible; however, both DNA strands completely melted apart in high concentrations of denaturant (over 
50\%) denaturants because GC clamp held together. From this analysis perpendicular DGGE, we were able to define a narrower denaturing gradient, 30 to $70 \%$, thereby achieving better resolution in the separation of different sequences in denaturing gradient gels in parallel.

\section{Determination of the optimal electrophoresis time}

To determine the length of electrophoresis time, we performed a so-called "time travel" experiment [48]. Figure 6 shows the results of this experiment. Two samples, PCR fragments of D. gigas, one with and one without a GC clamp, were loaded at 30-min intervals for up to $5 \mathrm{~h}$ onto a polyacrylamide gel containing a 30 to $70 \%$ linear gradient of denaturants. Between 120 and $150 \mathrm{~min}$ of electrophoresis, the PCR fragment with GC clamp starts to melt and stopped abruptly in the electrophoresis, while the PCR fragment without the GC clamp melts completely into two single strands and did not stop. Further experiments were therefore performed with the GC clamp PCR primer, a gradient of 30 to $70 \%$ denaturants, and an electrophoresis time of $4 \mathrm{~h}$ to obtain good separation between PCR fragments of different Desulfovibrio species.

\section{DGGE analysis}

The resolution of this hydrogenase DGGE analysis was first tested with amplified PCR fragments obtained from pure cultures of Desulfovibrio species. The [NiFe] hydrogenase genes of seven different Desulfovibrio species, i.e., D. sulfodismutans, D. gigas, D. vulgaris BCMPS82, D. Desulfuricans BCMPS79, D. baculatus, SRB isolate A were amplified with primer pair Hyd1FHyd5R with GC clamp, and loaded onto a polyacrylamide gel containing a linear increasing gradient from 30 to $70 \%$ denaturants. As is shown in Figure 7, we were able to separate the amplified hydrogenase fragments from these species on a polyacrylamide gel containing a gradient of DNA denaturants.

\section{Analysis of genetic diversity}

We analyzed the $[\mathrm{NiFe}]$ hydrogenase sequences amplified from four different environmental samples, i.e., from three different wastewater treatment reactors and from a microbial mat. For two of the bioreactors, we obtained one band (Figure 7, lanes 8 and 10, respectively); for the other bioreactor sample, we found two bands

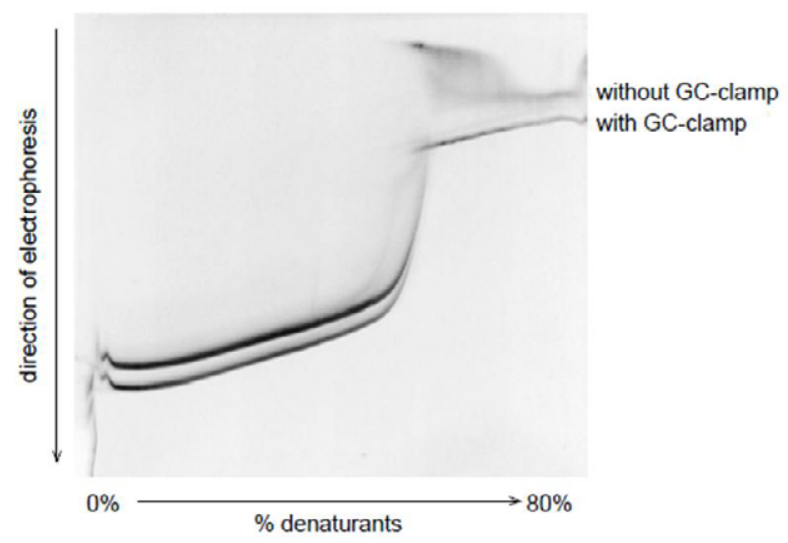

Figure 5: Negative image of an ethidium bromide-stained perpendicula DGGE separation pattern of PCR-amplified [NiFe] hydrogenase gene fragments from $D$. vulgaris BCMPS82obtained with primer pair Hyd1FHyd5R without GC clamp and with GC clamp. The fragment without GC clamp shows no stable melting behavior; it falls apart in two single-stranded molecules at high denaturant concentrations.

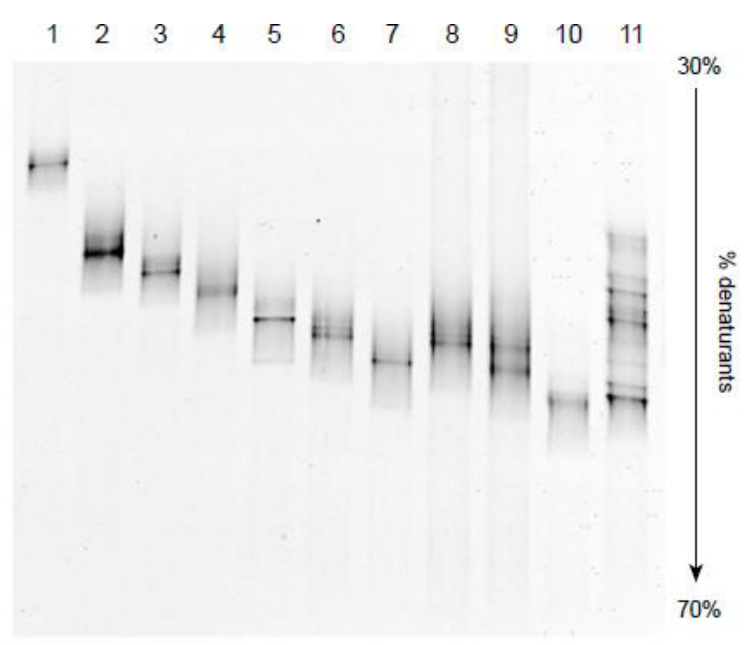

Figure 6: "Time travel" experiment. The figure shows a negative image of an ethidium bromide-stained DGGE separation pattern of PCR- amplified [NiFe] hydrogenase fragments from D.gigaswith GC clamp and without GC clamp. The different samples were loaded onto the gel every 30 min (30') for a total of $5 \mathrm{~h}$. Note that the fragments with GC clamp stop after about 2.5 $\mathrm{h}$ and do not move further into the gel even after $5 \mathrm{~h}$ of electrophoresis. The fragments without GC clamp, however, slowdown but do not stop.

(Figure 7, lane 9). There were at least five bands present in the microbial mat sample (Figure 7, lane 11).

\section{Discussion}

Explicitly describe a molecular approach to the analysis of genetic diversity in the species Desulfovibrio environmental samples. Other molecular methods have also attempted to fulfil this purpose. 16S rRNA-targeted oligonucleotide probes have been successfully used to detect SRB in environmental samples. However, these probes are designed to detect all [49] or any subgroup [50] SRB. No speciesspecific probes were described some of the SRB, including members of the genus Desulfovibrio. Furthermore, no new information sequence was obtained by the following approach. Voordouw et al. [24] uses a combination of the four DNA probes for different hydrogenase genes for detecting species of Desulfovibrio in environmental samples, but we enrich previous molecular identification of bacteria. In later studies, a technique called reverse sample genome scan described for the identification of different populations SRB oil fields. Otherwise genome scan analysis of the sample DNA is extracted from the sample in the environmental field, which are labelled and hybridized with 'the main filter,' which contains the denatured genomic DNA from bacteria isolated from the target environment. In this way, the researchers were able to identify which of the bacterial genomes spotted main filter were most prevalent in the samples. This approach has been successfully applied to distinguish between two different bacterial communities, i.e., both savory and sweet SRB [52]. The advantage of this method is that it is not limited to one phylogenetic groups of microorganisms, such as species of Desulfovibrio, but that can be used to detect all bacteria isolated from a particular environment. However, as indicated by the researchers [53], the problem may be the isolation of ecologically important organisms. Furthermore, phylogenetic inference detected community members is not possible because no nucleotide sequences of natural DNA samples are loaded by this approach. PCR amplification of individual genes to identify the bacteria depends on the isolation of bacteria from detection, but it is only possible for those bacteria for which there is sufficient information sequence. However, although not 
completely error free, advantages DGGE analysis of PCR-amplified gene fragments are manifold; the method is rapid (about $10 \mathrm{~h}$ for PCR and DGGE), simple (only molding polyacrylamide gel), and inexpensive. The sample to sample comparison is possible because more samples (20 samples for our system) can be analyzed simultaneously on one gel. But the most important advantage is that separate DGGE bands can be sequenced directly without cloning [54-56], which will allow us to create storage nucleotide sequence database, from which one can infer the phylogenetic affiliation of new species and from which species-specific probes can be designed. DGGE analysis limitation is that only relatively small fragments, up to $500 \mathrm{bp}$ can be analyzed. Here we have used this approach to molecular analysis of genetic diversity in the species Desulfovibrio different environments. It is based on the separation of PCR-amplified fragments [NiFe] hydrogenase gene DGGE. We chose this gene because (i) it is present in all species of Desulfovibrio, and (ii) it can help us understand the importance of reducing metal SRB. Voordouw et al. [24] studied the distribution of the three types of hydrogenase genes among the 22 members of the genus Desulfovibrio and found that the [NiFe] hydrogenase gene was present in all the species Desulfovibrio, while genes for [Fe] hydrogenase and $[\mathrm{NiFeSe}]$ hydrogenase had more limited distribution. Lovley et al. $[22,23]$, it was found that hydrogenases $D$. vulgaris play an indirect role in the reduction of uranium. He even claimed that SRB give priority to reducing the metal over the sulphate reduction under certain conditions, such as low hydrogen concentration. As mentioned earlier, the reduction of oxidized metals such as iron and manganese may be more important metabolic process of oxidation of organic carbon in anoxic marine sediments [57]. However, from these studies it was clear that organisms play a role in this process.

Some researchers have suggested that the SRB may be the key players $[22,23]$. Therefore, to understand the importance of the metal reduction SRB, we must determine the hydrogenase activity of SRB in these environments, where there is a reduction metal. Preliminary experiments carried out by us (results not shown) indicate žeexprese [NiFe] hydrogenase gene can be detected by reverse transcriptase PCR [24], and Desulfovibrio žeidentita active ingredient can be determined by DGGE analysis sub- sequent reverse transcriptase PCR products. By using different sets of primers were able to amplify [NIDV] hydrogenase gene in all species Desulfovibrio tested. A positive result on the new SRB isolate PIB2 indicates that it is a kind of Desulfovibrio. This result was supported by phylogenetic analysis of the $16 \mathrm{~S}$ rDNA (results not shown); a group with other species Desulfovibrio, while isolate LTK4 which gave a positive result in our PCR assay was in connection with Desulfobulbus species (34a). For some species, it was possible to obtain a product with only one PCR primer pair. The use of other primer pairs gave a PCR product. This may mean that for some target sequences of PCR primers can vary in these species. For two species, D. vulgaris DSM 1744 and D. longus, we obtained a specific product from primer pair Hyd1F-Hyd5R has been used less stringent amplification protocol. For D. vulgaris, we received only one PCR product, when used primer pair Hyd2F-Hyd7R. This pair of primers also gave PCR products with some of the other bacteria, such as D. variabilis, D. baarsii, Escherichia coli, Xanthobacter autotrophicus, and Pseudomonas denitrificans. Therefore, the target sites for the primers were probably more conservative than with other primer pairs. Using primer pair Hyd1F-Hyd5R, we were able to amplify the $[\mathrm{NiFe}]$ hydrogenase gene from various environmental samples, thereby detecting the presence of Desulfovibrio species in these samples. However, only after DGGE analysis of these PCR products, we were able to determine genetic diversity Desulfovibrio species in these samples. In two samples of bioreactor, we found only one strip, which means that from one species Desulfovibrio. In one sample of the bioreactor, we found two bands, indicating the presence of two different species of Desulfovibrio. The microbial mat sample, we found at least five dominant bands, which would indicate the presence of at least five different species that make up this community. This high number of different species of Desulfovibrio microbial mat may be surprising; However, Devereux Mundfrom [58] recently found a high degree of genetic diversity SRB in sandy marine sediment sample. Thirteen unique sequences, derived from cloned PCR products of $16 \mathrm{~S}$ rDNA grouped with SRB in delta subclass Proteobacteria. From these results we concluded that genetic diversity Desulfovibrio species within the natural microbial mat is much higher than in the experimental bioreactors. In summary, DGGE analysis of PCR products obtained after amplification of the [NiFe] hydrogenase gene from genomic DNA isolated from environmental samples reveals the genetic diversity of the species Desulfovibrio in these samples. Along with DGGE analysis of PCR products obtained after amplification of mRNA, we hope to identify niche differentiation between the different kinds of Desulfovibrio and applied first community structure community features.

\section{References}

1. Jørgensen B B (1982) Mineralization of organic matter in the sea bed -the role of sulfate reduction. Nature (London) 296:643-645.

2. Sass H, Cypionka H, Babenzien HD (1997) Vertical distribution ofsulfatereducing bacteria at the oxic-anoxic interface in sediments of the oligotrophic Lake Stechlin. FEMS MicrobiolEcol 22: 245-255.

3. Davey ME,O'toole GA (2000) Microbial biofilms: from ecology to molecular genetics. MicrobiolMol Biol Rev 64: 847-867.

4. Raskin L, Amann RI, Poulsen LK, Rittmann BE, Stahl DA (1995) Use of ribosomal RNA-based molecular probes for characterization of complex microbial communities in anaerobic bio? Lms Water SciTechnol 31: 261-272.

5. Rabus R, Fukui M, Wilkis H, Widdel F (1996) Degradative capacities and $16 \mathrm{~S}$ rRNA-targeted whole-cell hybridization of sulfate-reducing bacteria in an anaerobic environment culture utilizing alkylbenzenes from crude oil. Appl Environ Microbiol 62: 3605-3613.

6. Okabe S, Itoh T, Satoh H, Watanabe Y (1999) Analyses of spatial distributions of sulfate-reducing bacteria and their activity in aerobic wastewater biofilms. Appl Environ Microbiol 65: 5107-5116.

7. Krekeler D, Sigalevich P, Teske A, Cypionka H, Cohen Y (1997) Asulfatereducing bacterium from the oxic layer of a microbial mat from Solar Lake (Sinai), Desulfovibriooxyclinae sp. nov. Arch Microbiol 167: 369-375.

8. Ramsing NB,Kühl M, Jørgensen BB (1993) Distribution of sulfate-reducing bacteria, $\mathrm{O}$ and $\mathrm{H} 2 \mathrm{~S}$ in photosynthetic biofilms determined by oligonucleotide probes and microelectrodes. Appl Environ Microbiol 59: 3840-3849.

9. Ravenschlag K,Sahm K, Knoblauch C, Jørgensen BB, Amann R (2000) Community structure, cellular rRNA content, and activity of sulfate-reducing bacteria in marine arctic sediments. Appl Environ Microbiol 66: 3592-3602.

10. Minz, D, Flax JL, Green SJ, Muyzer G, Cohen Y, et al. (1999) Diversity of sulfate-reducing bacteria in oxic and anoxic regions of a microbial mat characterized by comparative analysis of dissimilatorysul? te reductase genes. Appl Environ Microbiol 65: 4666-4671.

11. Wawer C Muyzer G (1995) Genetic diversity of Desulfovibrio spp. in environmental samples analyzed by denaturing gradient gel electrophoresis of [NiFe] hydrogenase gene fragments. Appl Environ Microbiol 61: 2203-2210.

12. Daly K, Sharp RJ, McCarthy AJ (2000) Development of oligonucleotide probes and PCR primers for detecting phylogenetic subgroups of sulfate-reducing bacteria. Microbiology $146: 1693-1705$

13. Loy A,Lehner A, Lee N, Adamczyk J, Meier H, et al. (2002) Oligonucleotide microarray for $16 \mathrm{~S}$ rRNA gene-based detection of all recognized lineages of sulfate-reducing prokaryotes in the environment. Appl Environ Microbiol 68 5064-5081.

14. Santegoeds CM Damgaard LR, Hesselink G, Zopfi J, Lens P, et al. (1999) 
Citation: Shah MP (2015) Exploitation of Denaturing Gradient Gel Electrophoresis in Analysis of Microbial Diversity. J Microb Biochem Technol 7: 112-119. doi:10.4172/1948-5948.1000191

Distribution of sulfate-reducing and methanogenic bacteria in anaerobic aggregates determined by microsensor and molecular analyses. Appl Environ Microbiol 65: 4618-4629.

15. Heuer H, Smalla K (1997) Application of denaturing gradient gel electrophoresis (DGGE) and temperature gradient gel electrophoresis (TGGE) for studying soil microbial communities. In: van Elsas JD, Wellington EMH, Trevors JT (Eds), Modern soil microbiology. Marcel Dekker Inc., New York.

16. Muyzer G, de Waal EC, Uitterlinden AG (1993) Profling of complex microbial populations by denaturing gradient gel electrophoresis analysis of polymerase chain reaction ampli?ed genes coding for $16 \mathrm{~S}$ rRNA. Appl Environ Microbio 59: $695-700$.

17. Saiki RK,Gelfand DH, Stoffel S, Scharf SJ, Higuchi R, et al. (1988) Primerdirected enzymatic amplification of DNA with a thermostable DNA polymerase. Science 239: 487-491.

18. Abrams ES, Stanton VP Jr (1992) Use of denaturing gradient gel electrophoresis to study conformational transitions in nucleic acids. Methods Enzymol 212: 71 104

19. Fischer SG, Lerman LS (1983) DNA fragments differing by single base-pair substitutions are separated in denaturing gradient gels: correspondence with melting theory. Proc Natl AcadSci U S A 80: 1579-1583.

20. Myers RM, Maniatis T, Lerman LS (1987) Detection and localization of single base changes by denaturing gradient gel electrophoresis. Methods Enzymol 155: 501-527.

21. Voordouw G (1990) Hydrogenase genes in Desulfovibrio. In:Belaich JP Bruschi M, Garcia JL (Eds), Microbiology and biochemistry of strict anaerobes involved in interspecies hydrogen transfer. Plenu Press, New York.

22. Lovley DR, Roden EE, Phillips EJP, Woodward JC (1993) Enzymatic iron and uranium reduction by sulfate-reducing bacteria. Mar Geol 113:41-53.

23. Lovley DR, Widman PK, Woodward JC, Phillips EJ (1993) Reduction of uranium by cytochrome c3 of Desulfovibrio vulgaris. Appl Environ Microbio 59: 3572-3576.

24. Voordouw G,Niviere V, Ferris FG, Fedorak PM, Westlake DW (1990) Distribution of Hydrogenase Genes in Desulfovibrio spp. and Their Use in Identification of Species from the Oil Field Environment. Appl Environ Microbio 56: 3748-3754.

25. Muyzer G, de Waal EC, Uitterlinden AG(1993) Profiling of complex microbial populations by denaturing gradient gel electrophoresis analysis of polymerase chain reaction-amplified genes coding for $16 \mathrm{~S}$ rRNA. Appl Environ Microbio 59:695-700

26. Muyzer G, de Waal EC (1994) Determination of the genetic diversity of microbia communities using DGGE analysis of PCR-amplified 16S rDNA. In: StalJ, Caumette $P$ (Eds), Microbial mats-structure, development and environmental significance. NATO ASI series G35. Springer, Berlin.

27. Don RH, Cox PT, Wainwright BJ, Baker K, Mattick JS (1991) 'Touchdown' PCR to circumvent spurious priming during gene amplification. Nucleic Acids Res 19: 4008.

28. Neufeld JD, Schafer H, Cox MJ, Boden R, McDonald IR, et al. (2007) Stableisotope probing implicates Methylophaga spp. and novel Gammaproteobacteria in marine methanol and methylamine metabolism. ISME J 1: 480-491.

29. Moore TA, Xing Y, Lazenby B, Lynch MD, Schiff S, et al. (2011) Prevalence of anaerobic ammonium-oxidizing bacteria in contaminated groundwater. Environ SciTechnol 45: 7217-7225.

30. Green SJ, Leigh MB, Neufeld JD (2010) Denaturing gradient gel electrophoresis (DGGE) for microbial community analysis. In: Timmis K (Eds), Hydrocarbon Microbiology. Springer, Berlin.

31. Uitterlinden AG, Mullaart EM, Morolli B, Vog J (1991) Genome scanning of higher eukaryotes by two-dimensional DNA typing using micro- and minisatellite core probes. Methods (a companion to Methods Enzymol) 3:83-90.

32. Amann RI, Binder B, Chisholm SW, Olsen R, Devereux R, et al. (1990) Combination of $16 \mathrm{~S}$ rRNA-targeted oligonucleotide probes with flow cytometry for analyzing mixed microbial populations. ApplEnvironMicrobiol 56:1919-1925.

33. Deckers HM, Wilson FR, Voordouw G (1990) Cloning and sequencing of a [NiFe] hydrogenase operon from Desulfovibrio vulgaris Miyazaki F. J Gen Microbiol 136: 2021-2028.
34. Rousset M,Dermoun Z, Hatchikian CE, Bélaich JP (1990) Cloning and sequencing of the locus encoding the large and small subunit genes of the periplasmic [NiFe]hydrogenase from Desulfovibriofructosovorans. Gene 94 95-101.

35. Li C, Peck HD Jr, LeGall J, Przybyla AE (1987) Cloning, characterization, and sequencing of the genes encoding the large and small subunits of the periplasmic [NiFe]hydrogenase of Desulfovibriogigas. DNA 6: 539-551.

36. Devereux J, Haeberli P, Smithies O (1984) A comprehensive set of sequence analysis programs for the VAX. Nucleic Acids Res 12: 387-395.

37. Pearson WR (1990) Rapid and sensitive sequence comparison with FASTP and FASTA. Methods Enzymol 183: 63-98.

38. Pearson WR,Lipman DJ (1988) Improved tools for biological sequence comparison. Proc Natl AcadSci U S A 85: 2444-2448.

39. Deckers HM, Wilson FR, Voordouw G (1990) Cloning and sequencing of a [NiFe] hydrogenase operon from Desulfovibrio vulgaris Miyazaki F. J Gen Microbiol 136: 2021-2028.

40. Devereux R, Delaney M, Widdel F, Stahl DA (1989) Natural relationships among sulfate-reducing eubacteria. J Bacteriol 171: 6689-6695.

41. Voordouw G, Niviere V, Ferris FG, Fedorak PM, Westlake DW (1990) Distribution of Hydrogenase Genes in Desulfovibrio spp. and Their Use in Identification of Species from the Oil Field Environment. Appl Environ Microbio 56: $3748-3754$

42. Don RH, Cox PT, Wainwright BJ, Baker K, Mattick JS (1991) 'Touchdown' PCR to circumvent spurious priming during gene amplification. Nucleic Acids Res 19: 4008.

43. Lerman LS, Silverstein K (1987) Computational simulation of DNA melting and its application to denaturing gradient gel electrophoresis. Methods Enzymol 155: 482-501.

44. Sheffield VC, Cox DR, Lerman LS, Myers RM (1989) Attachment of a 40-base-pair G + C-rich sequence (GC-clamp) to genomic DNA fragments by the polymerase chain reaction results in improved detection of single-base changes. Proc Natl AcadSci U S A 86: 232-236.

45. Abrams ES, Stanton VP Jr (1992) Use of denaturing gradient gel electrophoresis to study conformational transitions in nucleic acids. Methods Enzymol 212: 71 104

46. Myers RM, Maniatis T, Lerman LS (1987) Detection and localization of single base changes by denaturing gradient gel electrophoresis. Methods Enzymo 155: $501-527$

47. Muyzer G, de Waal EC, Uitterlinden AG (1993) Profiling of complex microbia populations by denaturing gradient gel electrophoresis analysis of polymerase chain reaction-amplified genes coding for $16 \mathrm{~S}$ rRNA. Appl Environ Microbio 59:695-700.

48. Amann RI, Binder BJ, Olson RJ, Chisholm SW, Devereux R, et al. (1990) Combination of $16 \mathrm{~S}$ rRNA-targeted oligonucleotide probes with flow cytometry for analyzing mixed microbial populations. Appl Environ Microbiol 56: 1919 1925.

49. Devereux R, Kane MD, Winfrey J, Stahl DA (1992) Genus- and group-specific hybridization probes for determinative and environmental studies of sulphatereducing bacteria. SystAppIMicrobiol 15:601-609.

50. Voordouw G, Shen Y, Harrington CS, Telang AJ, Jack TR, et al. (1993) Quantitative reverse sample genome probing of microbial communities and its application to oil field production waters. Appl Environ Microbiol 59: 4101-4114.

51. Voordouw G,Voordouw JK, Jack TR, Foght J, Fedorak PM, et al. (1992) Identification of distinct communities of sulfate-reducing bacteria in oil fields by reverse sample genome probing. Appl Environ Microbiol 58: 3542-3552.

52. Voordouw G, Voordouw JK, Karkhoff-Schweizer RR, Fedorak PM, Westlake DWS (1991) Reverse sample genome probing, a new technique for identification of bacteria in environmental samples by DNA hybridization, and its application to the identification of sulfate-reducing bacteria in oil field samples. Appl Environ Microbiol 57:3070-3078.

53. Muyzer G, de Waal EC(1994) Determination of the genetic diversity of microbial communities using DGGE analysis of PCR-amplified 16S rDNA. In: Sta LJ,Caumette P (Eds), Microbial matsstructure, development and environmental significance. NATO ASI series G35. Springer, Berlin.

54. Muyzer G, Hottentrager S, Teske A,Wawer C(1995) Denaturing gradient ge 
Citation: Shah MP (2015) Exploitation of Denaturing Gradient Gel Electrophoresis in Analysis of Microbial Diversity. J Microb Biochem Technol 7: 112-119. doi:10.4172/1948-5948.1000191

electrophoresis of PCR-amplified 16S rDNA-a new molecular approach to analyse the genetic diversity of mixed microbial communities. In: Akkermans ADL, van Elsas JD, de Bruijn FJ (Eds), Molecular microbial ecology manual. Dordrecht, The Netherlands.

55. Canfield DE, Jorgensen BB, Fossing H, Glud R, Gundersen J, et al. (1993)
Pathways of organic carbon oxidation in three continental margin sediments. Mar Geol 113: 27-40

56. Devereux R,Mundfrom GW (1994) A phylogenetic tree of 16 S rRNA sequences from sulfate-reducing bacteria in a sandy marine sediment. Appl Environ Microbiol 60: 3437-3439. 